\title{
Discussion on anti-floating stability of tall building basement
}

\author{
Zhanming $\mathrm{Fu}^{1, \mathrm{a}}$, Quan Bai ${ }^{2, \mathrm{~b}^{*}}$ \\ ${ }^{1}$ N.E.U Engineering \& Research Institute Co., Ltd., Shenyang, China \\ ${ }^{2}$ School of Architecture and Civil Engineering, Shenyang University of Technology, Shenyang, China \\ a1017497239@qq.com, bbaiquan@163.com
}

Keywords: tall buildings; basement; anti-floating fortification water level; the anti-floating stability Abstract. Anti-floating stability of tall building basement is important content of engineering design, inappropriate design will cause motherboard cracking or basement floating, which influence service function directly or even endanger structure safety. Although our national specifications has attached more attention to this problem, because of understanding deviation on related concepts, troubles still always appear in engineering. Combined with a project example, the causes of basement floating are analyzed in this paper. On this basis, aiming at different stages such as construction and service, some suggestions of basement anti-floating design on anti-floating stability factors values and matters needing attention in construction are provided for reference in engineering design.

\section{Introduction}

Tall buildings are more and more widely used in either big cities or middle and small cities. In tall buildings, one-layer and two-layer basements are very commonly seen. Sometimes, even multi-layer basements are also used. Thus, the anti-floating is particularly prominent. In national codes, more and more attentions are paid to anti-floating stability checking calculation. Other relevant departments, such as geotechnical engineering investigation, design, construction and supervision department, and so on, should also pay great attention to basement anti-floating. Combined with a typical project example, main points should be paid attention to in basement anti-floating stability design of tall buildings are discussed in detail.

\section{Anti-floating design of basement}

Anti-floating stability checking calculation. In Code for design of building foundation of 2002 proscribed that anti-floating stability checking calculation should be done if underground water level is higher and basement or underground building may float up. This regulation is mandatory and should be rigorously executed. The 2011 edition increased anti-floating stability calculation method[1], as follows: For the simple condition of buoyancy force, anti-floating stability of foundation should meet the requirement:

$$
G_{\mathrm{k}} / N_{W, \mathrm{k}} \geq K_{W}
$$

Where $G_{\mathrm{k}}$ is the sum of building dead weight and external $\operatorname{load}(\mathrm{kN}), N_{W, \mathrm{k}}$ is the value of buoyancy force $(\mathrm{kN})$, and $K_{W}$ is the anti-floating stability safety factor with general value of 1.05.

Considering the action of underground water, floor components of basement foundation must have enough strength and stiffness. Bending, shear and punching bearing capacity checking calculations are also necessary

Anti-floating fortification water level. Current code clearly stipulates that survey report should provide anti-floating fortification water level. In addition, it should provide relevant technical parameters of foundation pit dewatering and advised method of underground water controlling.

Anti-floating fortification water level is an important design parameter, and following key points should be paid more attention to:

It is a dynamic and varies with many influence factors, such as construction dewatering measures 
of adjacent building and increased rainfall in rainy season, and so on. In big cities, it is necessary to set up special department similar to weather station to accumulate and collect long-term underground water level resources, which will supply reliable data for engineering construction. Anti-floating fortification water level of important buildings should be discussed and defined by multi-sectors if necessary.

During construction and service period, different most unfavorable values of anti-floating fortification water level should be used according to specific place and time, especially in construction period.

\section{Typical case}

Basic information of main structure. An engineering project in one city, which concludes 8 high residences varying from 13 to 20 layers with building area of 150 thousands square meter, cast-in-place reinforced concrete structure. The height of each storey is $2.9 \mathrm{~m}$. Elevations of roof board structure are 37.700 and $58.850 \mathrm{~m}$ respectively. The elevation difference between indoor and outdoor is $0.6 \mathrm{~m}$, which can be seen in the profile (Fig. 1). The first and second storey underground is the garage of cast-in-place reinforced concrete structure with ribbed beam and plate floor.

For the first floor underground, the storey height is $4.2 \mathrm{~m}$ and the section size of frame beam is $500 \mathrm{~mm} \times 900 \mathrm{~mm}$. For the second floor, above data are $4.3 \mathrm{~m}$ and $400 \mathrm{~mm} \times 800 \mathrm{~mm}$ respectively, in addition, the column spacing is $8.4 \mathrm{~m} \times 8.94 \mathrm{~m}$ and the section size of column is $600 \mathrm{~mm} \times 600 \mathrm{~mm}$. The total length and width size are $210 \mathrm{~m}$ and $68 \mathrm{~m}$ respectively. Settlement and temperature late poured band is set instead of expansion joint and settlement joint, which will be poured after two month when the main structure completing using no shrinkage concrete.

Aboveground structures are all shear walls structure systems. The underground part of tall building is shear wall, while, it is simple frame for other buildings. The roof thickness of first storey underground is $200 \mathrm{~mm}$ with $1.0 \mathrm{~m}$ covering soil. The roof thickness of second storey underground is $150 \mathrm{~mm}$ with $200 \mathrm{~mm}$ surface layer and drainage ditch. Frame column foundation of building except tall building consists of independent spread foundation and $350 \mathrm{~mm}$ waterproof bottom plate with -7.700m upper surface elevation. Raft foundation is used in tall buildings, and bearing stratum is the third layer moderately weathering sand shale with $600 \mathrm{kPa}$ bearing capacity eigen value.

Soil layer and groundwater. The soil from up to down consists of three layers, that is, miscellaneous fill, seriously weathered sand shale and moderately weathered sand shale. Miscellaneous fill consists of construction waste, broken brick and stone block, and massive. It is loose and contains massive silt and sand with bottom buried depth $1.60-1.90 \mathrm{~m}$. Seriously weathered sand shale is yellowish green or grey black and looks like hard plastic clay. The bottom buried depth is $6.80-7.30 \mathrm{~m}$ and the thickness is $5.2-5.40 \mathrm{~m}$. Moderately weathered sand shale is also grey black and looks like hard massive. The core looks like short prismatic and the maximum depth is $18.30 \mathrm{~m}$.

The distance from ground surface to stable groundwater level is $4.50 \mathrm{~m}$, and the annual average maximum change range is about $1.5 \mathrm{~m}$. The elevation of anti-floating fortification water level is $3.0 \mathrm{~m}$ under nature ground.

The groundwater has not corrosion on concrete and reinforced concrete.

Analysis and calculation of basement floating. This project began to construct in June 2011, and the main structure was completed in July 2013. The basement roof covering soil, flooring and wall plaster had not start. Just then, a rainstorm sustaining for more than twenty hours almost put the municipal drainage system into paralysis, and the whole city suffered serious flood.

The first day after rainstorm, cracks were found in stairs outdoor to indoor, as shown in Fig.2. Construction management technicians hold that crack reason is uneven settlement. While, after calculation, rechecking and careful analysis, design engineers thought that no problems. Afterward, the basement was found to be submerged in water $0.5 \mathrm{~m}$ depth, so drainage measures were taken immediately. After drainage, cracks appeared in joining frame beams between garage and high-rise part, roots of simple frame columns and filler wall of basement. Cracking mechanism is identical to 
frame beam and column cracks under horizontal earthquake action, and literature [2] has provided a reference.

By field observation and conference discussion, a consistent conclusion is drawn that water level increasing caused by rainstorm results in larger buoyancy than deadweight of building. Field measurement shows that the highest floating point has rose for $320 \mathrm{~mm}$.

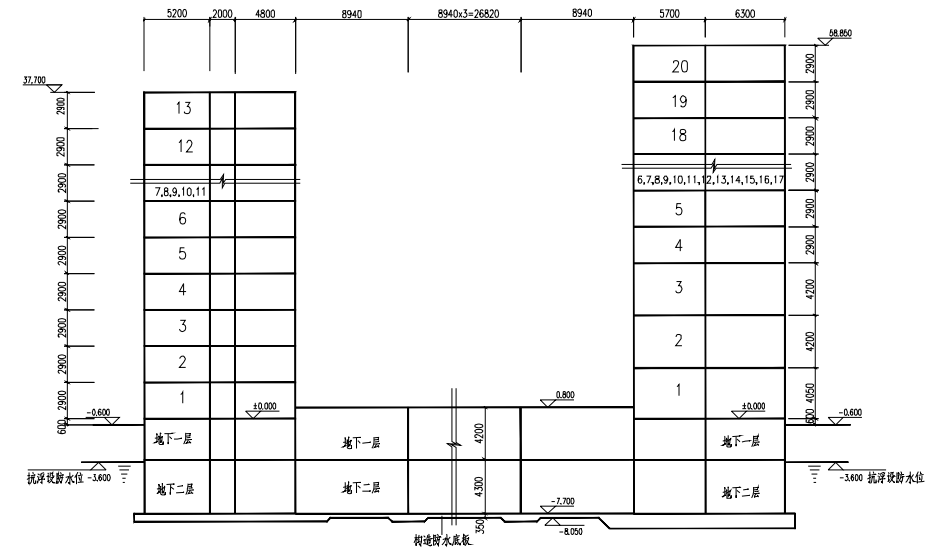

Fig.1 Profile schematic diagram

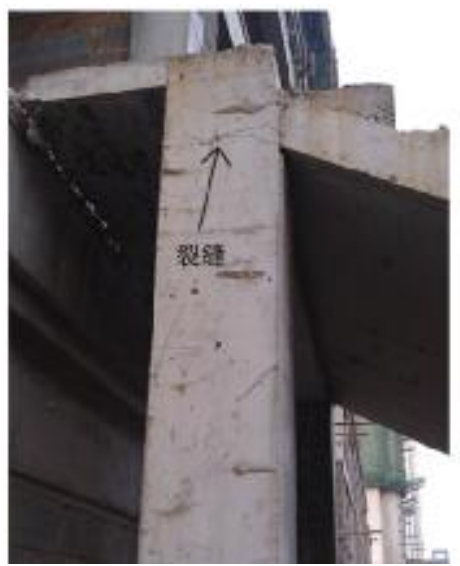

Fig. 2 Cracks of outdoor stair

Calculating on basement floating is as following:

It is assumed that connection joint of high-rise building and other part basement frame beam is fixed end, the load distribution is shown in Fig. 3(a). Anti-floating fortification water level $-3.600 \mathrm{~m}$ is taken as the highest water level and software PKPM is used in simulation calculation. The simulated deformation features accords with field actual situation, as shown in Fig. 3(b). Anti-floating stability checking calculation is shown as following:

(1)Deadweight of building:

Roof deadweight of underground first floor: $25 \times 0.2=5 \mathrm{kN} / \mathrm{m}^{2}$. Roof deadweight of underground second floor: $25 \times 0.15=3.75 \mathrm{kN} / \mathrm{m}^{2}$. $1 \mathrm{~m}$ covering soil deadweight of outdoor floor: $18 \times 1.0=18$ $\mathrm{kN} / \mathrm{m}^{2}$. Surface layer deadweight of underground first and floor: $20 \times 0.2=4 \mathrm{kN} / \mathrm{m}^{2}$. Surface layer deadweight of underground second floor: $20 \times 0.2=4 \mathrm{kN} / \mathrm{m}^{2}$. Top beam deadweight of underground first and second floor: $(0.5 \times 0.7+0.4 \times 0.65+0.35 \times 0.6+0.3 \times 0.6) \times 25 \times(8.94+8.4) /(8.94 \times 8.4)=5.77$ $\mathrm{kN} / \mathrm{m}^{2}$. Waterproof bottom plate deadweight: $25 \times 0.35=8.75 \mathrm{kN} / \mathrm{m}^{2}$

(2)Anti-floating stability checking calculation of service stage:

$G_{\mathrm{k}}=5+3.75+18+4 \times 2+5.77+8.75=49.27 \mathrm{kN} / \mathrm{m}^{2}, N_{W, \mathrm{k}}=10 \times(8.05 \cdot 3.6)=44.5 \mathrm{kN} / \mathrm{m}^{2}$

$K_{W}=G_{\mathrm{k}} / N_{W, \mathrm{k}}=49.27 / 44.5=1.11>1.05$

Above calculation shows that service stage anti-floating stability of basement meets code requirements.

(3)Anti-floating stability checking calculation when basement floating

$G_{\mathrm{k}}=5+3.75+5.77+8.75=23.27 \mathrm{kN} / \mathrm{m}^{2}, N_{W, \mathrm{k}}=10 \times(8.05 \cdot 3.6)=44.5 \mathrm{kN} / \mathrm{m}^{2}$

$K_{W}=G_{\mathrm{k}} / N_{W, \mathrm{k}}=23.27 / 44.5=0.523<1.05$

The result shows that if the basement floats up, the anti-floating stability cannot meet code requirement.

The main cause of basement anti-floating stability cannot meet standard requirements are that $1 \mathrm{~m}$ covering soil on the roof and $200 \mathrm{~mm}$ surface layers of underground first and second floor have not been constructed, which lead to enough upper weight. After well-point dewatering, the water level decreased and uplifted roof had a fallback gradually.

In order to prevent the basement from floating once again after rain, sand bags are added on the bottom plate as temporary weight. Strengthening construction has been done by specialized company and the strengthening methods are almost same with those described in literature[3-5]. 


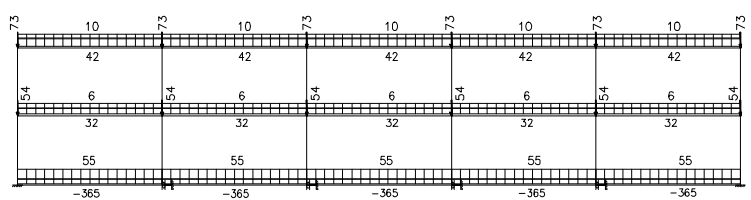

(a) Load diagram $(\mathrm{kN}, \mathrm{kN} / \mathrm{m})$

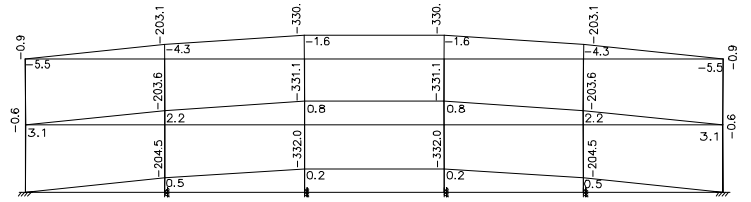

(b) Node displacement ( $\mathrm{mm})$

Fig.3 Load and displacement

\section{Anti-floating stability key problems of tall building basement}

Anti-floating stability checking calculation of building should be done in either construction or service stage. During construction, surface water of excavation is easy to inflows into foundation. If the foundation is impermeable layer such as rocks, water buoyancy on the foundation will suddenly increase, especially the underground garage adjacent to high-rise building basement. The reinforcement ratio of beam and column should be increased appropriately.

Anti-floating stability safety factors should be determined reasonably. Current codes described 1.05 as the lowest value. In fact, larger value should be used according to the complex degree of different engineering projects.

Problems need to be paid attention to in construction should be emphasized in design explanation. For example, in order to survey the periodic water level, permanent ground water level observation well needs to be set. After construction of basement, foundation pit should be backfilled immediately according to design requirements.

Anti-floating fortification water level provided by geotechnical exploration department should be examined carefully. It is suggested that different anti-floating fortification water level be used during construction and service period respectively.

The construction organization should establish feasible rainy season flood control scheme and adopt qualified dewatering measures reviewed by experts. Construction department in charge should enhance supervision and management on construction units, supervision units and estate developer, in case of engineering accidents during construction, such as basement uplifting and inclination, beam and column cracking.

\section{Acknowledgment}

This research was funded by the National Natural Science Foundation of China (No. 51204029), Department of education of Liaoning Province Scientific Research Foundation (No. L2013050) and the Scientific Research Foundation for Doctors of Shenyang University of Technology.

\section{References}

[1]GB 50007-2011. Code for design of building foundation[S].Beijing: China building industry press, 2012.

[2]WEI Da-ping. Analysis of local antiuplift instability of an underground garage and its strengthening[J]. Industrial Construction 2003,33(12):81-83.

[3]LAI Ying, JIN Guo-fang. Reinforcement treatment in floating resistance of an underground garage constrained by multi-towers around[J].Building Structure, 2010,40(2):84-86.

[4]Meng Fan-tao, YU Guang-ming, ZHAO Jian-feng. Simplified calculation and analysis of local anti-uplift instability of an underground garage and its strengthening treatment[J]. Building Structure, 2010,40(5):80-82.

[5]Liu Xiang-dong. Restoration practice and experience summary of a anti-floating engineering[J]. Building Structure, 2014,44(16):77-80. 